\section{... while Rome burns}

Trawling the news these days is becoming a depressing affair if you care about healthcare in South Africa (SA). A headline in Bizcommunity.com, 'Is Motsoaledi fiddling while healthcare is burning?', [1] 'Tygerberg Hospital must "be shut down and replaced", ${ }^{[2]}$ and in the midst of all this, 'NHI open for public comment soon ${ }^{[3]}$ these news stories have flooded the media in response to the recent tabling of a report by the Office of Health Standards Compliance (OHSC) to Parliament. In this report, only five of the 696 hospital and clinics that were inspected in 2016 - 2017 complied with the Department of Health's norms and standards to achieve an $80 \%$ 'pass mark'. And these inspections covered only one-fifth of SA's 3816 public health facilities.

Parliament's Portfolio Committee on Health was told on Wednesday 6 June 2018 that Tygerberg Hospital, the Western Cape's largest hospital, is in such a bad state that it needs to be shut down and replaced. Dr Beth Engelbrecht, Head of the Western Cape Department of Health, told the committee that it would cost an estimated ZAR10 billion to replace the hospital.

At the same time Health-e News reports that 'Limpopo health system is on the verge of collapse, ${ }^{3]}$ citing the results of a surprise visit paid to Polokwane Provincial Hospital by the South African Human Rights Commission, who found that expired food and medicines were being given to patients. Filing systems are in such chaos that new files are opened each time a patient visits the hospital because old files are lost. Hundreds of patients are transferred from underperforming regional hospitals, and a shortage of consulting rooms means that consultations are held in corridors, with scant regard for privacy or confidentiality.

As all this is hitting the news, our Minister of Health, Aaron Motsoaledi, is telling anyone who will listen that it is all an exaggeration and that he does not "know the yardstick that was used to arrive at a conclusion of collapse. Surely healthcare systems are measured on some form of scientific yardstick to arrive at any conclusion', apparently discounting the methods used by the OHSC the statutory body charged with assessing the quality of hospitals and clinics. This same body will be responsible for determining whether public health facilities are adequate for accreditation under the National Health Insurance (NHI) programme. The Minister does concede that overcrowding is a problem, but went on to point out the merits of the decentralised medication pick-up points, strangely disregarding the frequently reported stock-outs of medication at these facilities. And he waxed lyrical about our TB and HIV medication programmes, pointing out their sheer scale, in itself something of an indication of failures elsewhere in the public healthcare system.

We need a functioning public healthcare system in SA. Introducing NHI while our public facilities are in this parlous state is an enormous mistake. First fix what is broken hopefully not broken beyond repair - and then perhaps think about changing the system under which it is administered.

\section{Bridget Farham \\ Editor}

ugqirha@iafrica.com

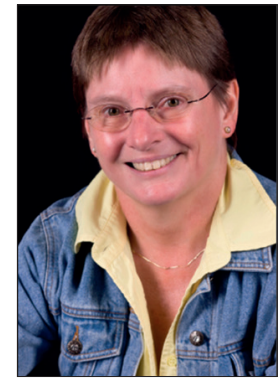

1. Bizcommunity.com. http://www.bizcommunity.com/Article/196/330/177967.html\#topstory (accessed 12 June 2018)

2. IOL. https://www.iol.co.za/capeargus/news/tygerberg-hospital-must-be-shut-down-andreplaced-15357136 (accessed 12 June 2018)

3. Bizcommunity.com. http://www.bizcommunity.com/Article/196/330/178100.html (accessed 12 June 2018)

4. Health-e News. https://www.health-e.org.za/2018/06/12/limpopo-health-system-on-the-verge-ofcollapse/ (accessed 12 June 2018)

S Afr Med J 2018;108(7):526. DOI:10.7196/SAMJ.2018.v108i7.13469 